ovaries the spring of the diaphragm may cause considerable discomfort. In such cases the use of an alternative type of cap, such as a vault-fitting Dumas or cervical cap, may be more suitable. The size of the cap required must be estimated. The diaphragm fits from the posterior fornix to the sub-pubic space, and a large range of sizes from which to select is required. Although fitting-rings may be used for this purpose, they are useless for instructing the patient.

It is important that the patient should be given careful instruction in locating her cervix and in placing the cap correctly. Instruction by diagrams or models alone is inadequate. Also instruction must be given in the use of a spermicidal jelly or cream with the cap-an essential part of the method. A subsequent examination must be carried out after the patient has practised placing the cap and returned with the cap in position. It is only at this examination that a final accurate estimation of the size of the cap required can be made. Subsequently routine checking of the satisfactory fit of the cap is advisable at six-monthly to yearly intervals. Post-natal refitting should always be carried out. From this it will be seen that it is impractical for a patient to fit herself with a Dutch cap.

\section{"Petrified Men" of Pompeii}

Q.-In "The Times" of October 8, 1956, a photograph was published of what was said to be "a petrified man found preserved in lava stone" at Pompeii. I have seen a number of these so-called "petrified men" in the museum at Pompeii in various attitudes which would suggest that they were fixed suddenly and rigidly where they were without even falling flat. Can you explain the mechanism by which a body could become petrified like this, or are they, as I suspect, fakes?

A.-The photograph in The Times is almost certainly of a plaster cast. The victims at Pompeii were overwhelmed by volcanic ash, not lava. (At Herculaneum the bodies were buried in lava.) After being moistened by rain, the ashes formed moulds round the bodies, which in the course of time disintegrated and left the moulds hollow. When these moulds are discovered they are filled with plaster to give a cast of the victim's body. All the "bodies" in the museum at Pompeii were produced in this way.

Sudden death probably accounts for the bizarre attitudes of the victims. Rapid death might have resulted from the inhalation of the hot dust and ashes, or from the inhalation of hydrogen sulphide. The first mechanism is in some ways comparable to the killing and fixation of machinegunners by flame-throwers in the second world war. It is well known that "sulphurous fumes" accompany the eruption of many volcanoes, and, although hydrogen sulphide is not usually considered a very rapid poison, in high concentration it is said to be as dangerous as hydrogen cyanide.

Tab. Codein. Co.

Q. - What is the maximum safe daily dose of tab. codein. co. (B.P.) in an adult for the relief of an acutely painful condition likely to persist for a week or ten days? What toxic effects should be watched for? How should the dose be modified for children? Are there any special contraindications?

A.-Tab. codein. co. (B.P.) are compound tablets each of which contains $7.5 \mathrm{mg}$. of codeine phosphate in addition to acetylsalicylic acid and phenacetin. The analgesic effect of tab. codein. co. is chiefly due to its aspirin and phenacetin rather than to its codeine content. There is no point in giving tab. codein. co. in large doses to relieve pain, for if the pain is so severe as to require very large doses of tab. codein. co. a stronger analgesic such as morphine, pethidine, or methadone is preferable. Doses in excess of two tablets of tab. codein. co. four-hourly, though possibly not dangerous, are undesirable as likely to cause nausea and vomiting. Constipation is usually the most troublesome side-effect of the drug, and in patients with prostatic hypertrophy or urethral stricture difficulty with micturition may be encountered. Codeine may cause vomiting, and rarely abdominal pain may develop-probably due to pylorospasm. The risks of respiratory depression are very small and do not increase as the dose of codeine is increased. Rarely allergic skin reactions may be seen. The recommended analgesic dose of codeine phosphate for children is 0.4 to $0.7 \mathrm{mg}$. per lb. (1.54 mg. per kg.), and therefore half to one compound tablet of codeine may be given four-hourly with safety. Codeine should be used with caution in patients with obstruction of the lower urinary tract, and should be avoided in those known to be allergic to it.

\section{Fluorides and Domestic Water-softeners}

Q.-Is the use of a domestic water-softener likely to affect the fluorine concentration in drinking-water?

A.-No. The common domestic water-softener is operated with base-exchange material which removes only the cations which cause hardness-that is, calcium and magnesium. The anions-chlorides, sulphates, fluorides, etc.-are not affected by passing through a column of base-exchange material.

\section{NOTES AND COMMENTS}

Rudolf Steiner Movement.-Dr. P. ENGEL (medical officer, Camphill Rudolf Steiner Schools, Bielside, Aberdeenshire) writes: In your reply ("Any Questions?" December 29, 1956, p. 1560) regarding schools for handicapped children established by the Rudolf Steiner movement, it is stated that the availability of this accommodation is limited by cost. At this particular residential school, which is the largest of its type in this country, the present fees are $£ 320$ a year for children sent by local authorities (plus £36 for extra expenses such as clothing); private children pay 7 guineas a week and the same extra expenses. This compares favourably with other residential schools and institutions. Ever since local authorities have sent children to us we have had a considerable waiting-list, and many requests for admission had to be declined owing to shortage of accommodation of staff and of capital rather than by cost to parents or local authorities. In $1956,65 \%$ of children at this school were paid for by local authorities in England and Scotland.

OUR EXPERT replies: Perhaps, if isolated, the remark that the availability of the accommodation is limited by cost may appear slightly ambiguous. But its meaning would surely have been quite clear to anyone reading the rest of the sentence, which ran as follows: "so that it (the accommodation) is in practice only accessible to those children whose parents can afford to pay for them, or in whose case public authorities are willing to pay for their tuition and care in one of the special schools or colonies." The correctness of this statement is borne out by Dr. Engel's letter.

Correction.-Dr. I. B. Sneddon asks us to correct an inadvertent error he made in his letter on varicose ulceration (Journal, January 5, p. 43). "The cause of varicose veins is chronic venous stasis" should have read "the cause of varicose ulcers ...."

Books of " Any Questions?" and Refresher Course Articles.The following books are available through booksellers or from the Publishing Manager, B.M.A. House. Prices include postage. Any Questions?, Volumes 2 and 3 (8s. each); Refresher Course for General Practitioners, Volumes 2 and 3 (26s. 6d. each inland, 26s. overseas); Clinical Pathology in General Practice (22s. 3d. inland, $21 \mathrm{~s}$. 9d. overseas).

All communications with regard to editorial business should be addressed to THE EDITOR, BRITISH MEdical JOURNAL, B.M.A. HoUSE, TAVISTOC SQUARE, LONDON, W.C.1. TELEPHONE: EUSTON 4499. TELEGRAMS: Aitiology, Westcent, London. ORIGINAL ARTICLES AND LETTERS orwarded for publication are understood to be

Medical Journal alone unless the contrary be stated. Authors desirng REPRINTS should communicate with the Publishin Manager, B.M.A. House, Tavistock Square, W.C.1, on receipt of proofs Authors overseas should indic

proofs are not sent abroad.

ADVRTISEMENTS should be addressed to the Advertisement Director. B.M.A. House, Tavistock Square, London, W.C.1 (hours 9 a.m. to D.m.). TELEPHO

Westcent, London. MEME Westcent. Liand

B.M.A. SCOTrish Office: 7. Drumsheugh Gardens, Edinburgh. 